\title{
DOI 10.32405/2218-7650-2018-6(35)-126-140
}

\section{УДК 364.442.2:044.14}

\section{Mariola Mirowska,}

Doktor nauk humanistycznych w zakresie pedagogiki, adiunkt; Kierownik Zakładu Pracy Socjalnej

i Rozwoju Społecznego;

Wydział Pedagogiczny, Uniwersytet Humanistyczno-Przyrodniczy

im. Jana Długosza w Częstochowie (Polska)

ORCID iD: https://orcid.org/0000-0002-4257-1528

mmirowska@interia.pl

\section{PROWADZENIE INDYWIDUALNEGO PRZYPADKU A CASE MANAGEMENT: ANALIZA TEORETYCZNA}

Streszczenie. Artykuł jest poświęcony refleksjom teoretycznym, dotyczącym analizy prowadzenia przypadku i Case Management, tłumaczone jako zarządzanie przypadkiem. W oparciu o analizę literatury przedmiotu, genezę i schemat założeń teoretycznych obie formuły umiejscowiono $\mathrm{w}$ metodzie pracy $\mathrm{z}$ indywidualnym przypadkiem. Metoda ta wywodzi się z gruntu amerykańskiego, a jej prekursorką była Mary Richmond. Kluczowe staje się nie tylko rozstrzyganie różnic i podobieństw w zakresie teoretycznym metody indywidualnych przypadków, ale także wyodrębnienie istotnych dwóch jej komponentów, które w praktyce wychowawczej, socjalnej, edukacyjnej itp. przyjmują odmienny przebieg. Zasadnicza różnica i korzyść, w przekonaniu autorki tego opracowania, w wymiarze praktyki pomocowej skłania na rzecz zainteresowania CM. W metodzie indywidualnych przypadków wyodrębniamy dwa jej komponenty. Jednym z nich jest rozpoznawanie sytuacji (wewnętrznej i zewnętrznej jednostki) problemowej (diagnoza sytuacji), prowadzące do sformułowania, wspólnie z potrzebującym planu pracy. Drugi komponent to praca $\mathrm{z}$ przypadkiem, na podstawie wcześniej ustalonego planu. Oba komponenty występują zarówno $\mathrm{w}$ pracy $\mathrm{z}$ indywidualnym przypadkiem prowadzonym $\mathrm{w}$ tradycyjnym znaczeniu jak i w Case Management (CM). W tym względzie Case Management może być taką formułą, która zawiera komponent indywidualnego podejścia do odbiorcy oraz obsługuje sieć powiązanych ze sobą usług, pochodzących z różnych źródeł, potrzebnych i dostarczanych jednostce $w$ odpowiedniej ilości we właściwym czasie. Zrozumienie idei Case Management i realizowanie jej na trzech poziomach polityki społecznej: normatywnym, organizacyjnym i operacyjnym $\mathrm{z}$ klientem, mogłoby dać szansę na sprawną reorganizację zindywidualizowanego i zintegrowanego systemu usług. Zarządzanie takim procesem to profesjonalna strukturyzacja przebiegu działania, zarządzanie obszarami oraz sieciami. 
Dla podnoszenia jakości praktyki pomocowej istotne jest badanie efektywności świadczonej pomocy w wymiarze metodycznego działania oraz technologii dostarczania usługi (wymiar ekonomiczny). W tym względzie właśnie Case Management to innowacyjna technologia organizacji i zarządzania strukturą organizacyjną instytucji, łącząca komponent indywidualnego podejścia do odbiorcy oraz obsługująca sieć powiązanych ze sobą usług.

Słowa kluczowe: case management, indywidualny przypadek, praca z indywidualnym przypadkiem, prowadzenie przypadku, obsługa sieci.

\section{WPROWADZENIE}

Problem. Prowadzenie indywidualnego przypadku i Case Management jako zarządzanie przypadkiem to procesy, sposoby działania z jednostką, oparte na teoretycznym i metodycznym działaniu. Jak dzisiaj rozumieć te dwa sposoby działania i do jakich wymiarów aktywności społecznej je odnosić? Co je różnicuje?

Przegląd literatury. Korzenie tych koncepcji możemy odnaleźć w metodologii badań społecznych. Refleksją teoretyczną, dającą nadbudowę dla tych sposobów metodycznego działania jest metoda pracy $\mathrm{z}$ indywidualnym przypadkiem. Podstawy teoretyczne i praktyczne dla tej metody wprowadziła Mary Richmond, wzmacniając tym samym kliniczny, medyczny model pracy (socjalnej), realizowany na terenie instytucji zdrowia. Opierała go na psychoanalizie, prowadzonej $\mathrm{w}$ psychoterapii, psychiatrii i psychologii klinicznej, koncentrującej się na indywidualnych problemach klientów. Jej założenia wykorzystywane są współcześnie do budowania strategii pomagania jednostce nie tylko w profesjonalnie świadczonej pomocy służb społecznych, czy medycznych (klinicznych) ale i edukacyjnych w wymiarze instytucjonalnym [3].

Case management zaś jako zarządzanie przypadkiem, wprowadza pewien element rozbudowujący organizację procesu pomagania, idący krok dalej niż tradycyjne prowadzenie przypadku [9]. Jednakże idea Case Management, jako model pomagania oparty na zasobach klienta i systemie zintegrowanych usług $\mathrm{w}$ jednym pakiecie znajduje zainteresowanie $w$ literaturze wzbogacającej praktykę służb społecznych, głównie pracy socjalnej: T. Kaźmierczak i M.Rymsza [4], A. Smrokowska-Reichmann [17], M. Mirowska [9] (Polska); H. Bevz [1], O. Savchuk [2] (Ukraina) czy też w pracy służb zatrudnienia [13].

W Niemczech Case Management znajduje się w wielu ustawach, dotyczących zatrudnienia, pomocy młodzieży, integracji osób z niepełnosprawnością czy w doradztwie imigracyjnym. W 2005 roku Case Management został tam znormalizowany i certyfikowany jako zawód [5]. Kształcenie w specjalności Case Management prowadzi się na kierunku Praca 
socjalna w Uniwersytecie Humanistyczno-Przyrodniczym im. Jana Długosza w Częstochowie [7].

\section{CEL I ZADANIA}

Artykuł ma charakter teoretyczny, bazujący na literaturze przedmiotu. Coraz częściej w praktyce życia społecznego pojawia się sformułowanie prowadzenie przypadku oraz Case Management (CM) tłumaczony na język polski jako zarządzanie przypadkiem. Pojawiające się w obu określeniach słowo przypadek, $\mathrm{w}$ pierwszym znaczeniu jako prowadzenie, a $\mathrm{w}$ drugim zarzqdzanie budzi wątpliwości i chaos rozumienia tych sformułowań, zwłaszcza dla działań praktycznych. Często pojawiające się zarzuty, że jedno i drugie sformułowanie znaczy to samo sprowadzają autorkę tego opracowania do wyznaczenia sobie celu jakim jest próba analizy rozumienia prowadzenia indywidualnego przypadku i Case Management ze szczególnym odniesieniem do praktyki ich stosowania.

Zadania badawcze sprowadzają się do:

1. Opisania sposobów/form działania oraz procesów je tworzących występujących w teorii.

2. Wykazania zasadniczych różnic w zastosowaniu praktycznym.

3. Nakreślenia kierunków zmian/modyfikacji badanych sposobów działania dla podnoszenia jakości praktyki pomocowej.

\section{TEORETYCZNE PODSTAWY BADAŃ}

Teoretyczne podstawy badań stanowi podejście psychospołeczne osadzone w teorii systemów. Według J. Krzyszkowskiego «Koncepcja systemów, łączy w sobie terapeutyczną (skoncentrowaną na jednostce) i reformatorską (nastawioną na zmianę środowiska) tradycję w pomocy społecznej i pracy socjalnej. Analiza systemowa praktyki pracy socjalnej opiera się na założeniu o zależności jakości życia klientów pomocy społecznej od systemów wsparcia znajdujących się w ich środowisku społecznym» [6]. Wykorzystywanie tej koncepcji prowadzi do rozbudowy konstruktów teoretycznych, co daje możliwości pogłębionego opisu procesów, zjawisk itp. w doskonalących je formach, a w perspektywie praktycznej wskazuje na efekty współpracy, które mnożą praktyczne osiągnięcia każdego elementu systemu w trakcie ich interakcji.

\section{METODY BADAŃ}

Metodą badawczą była teoretyczna analiza źródeł literatury w odniesieniu do sformułowanego problemu badawczego. Porównanie dwóch pojęć, które opisują te metody (prowadzenie przypadku i Case Management) w kontekście ich praktycznych i teoretycznych aspektów. 


\section{WYNIKI BADAŃ}

Prowadzenie indywidualnego przypadku a case management. Praca $\mathrm{z}$ przypadkiem to metoda pracy, która koncentruje się na podmiocie, a konkretnie na jego wieloproblemowej sytuacji. Praca ta, wykonywana przez profesjonalnie przygotowanego pracownika ma pomóc podmiotowi w wyjściu z trudnej sytuacji, której sam nie jest $w$ stanie podołać. Skoro celem tej pracy jest pomoc to niewątpliwie sięga korzeniami filantropii. Już w XIX wieku organizacje dobroczynne $\mathrm{w}$ trosce o usprawnienie swojej działalności podjęły trud usystematyzowania swojej działalności, tworząc w 1869 roku Związek Organizacji Dobroczynnych (Charity Organization Society). To właśnie w tej organizacji pojawił się pomysł metody pracy $\mathrm{z}$ indywidualnym przypadkiem. Ideą przewodnią $\mathrm{w}$ prowadzeniu tej pracy było założenie selekcji osób, którym ta pomoc będzie świadczona. Pojawia się etap rekrutacji. Kryterium wyjściowym do podjęcia pracy, a raczej współpracy jest gotowość, chęć osoby potrzebującej pomocy do wyjścia z trudnej sytuacji. Gorącym orędownikiem tak rozumianej idei pomocy był Charles Steward Loch (działacz i prezes w latach 1875-1913 Związku Organizacji Dobroczynnych) [3]. Można więc pokusić się o stwierdzenie, że następuje unaukowienie działań filantropijnych, przez porządkowanie wytycznych do pracy z osobą potrzebującą pomocy. Aby pomoc została udzielona, a konkretnie rozpoczęta jednostka jej oczekująca powinna wyrazić wolę chęci, gotowość do zmiany. Loch zakładał, że jednostka jest w stanie wyjść z ubóstwa, pod warunkiem wypracowania w sobie odpowiednich cech charakteru, takich jak pracowitość, gospodarność czy wola walki. Takie podejście do jednostki i jej roli $\mathrm{w}$ procesie pomagania (bo tak można rozumieć metodę pracy $\mathrm{z}$ przypadkiem) wynikała z przeświadczenia, że los każdego człowieka «leży w jego rękach». Na nic zdają się uwarunkowania społeczno-ekonomiczne, jeśli jednostka nie wyuczy się wartości potrzebnych do kierowania swoimi wyborami i ponoszenia za nie odpowiedzialności. Dlatego Loch był tak zdecydowanym przeciwnikiem rozdawnictwa pieniędzy dla szerokich wówczas rzesz żebrających i oczekujących na wsparcie głównie finansowe czy rzeczowe. Nie oznacza to jednak, że wykluczano w tej metodzie formę wsparcia pieniężnego. Jednak, ucząc pracy i godności do pracy, a przez to do samego siebie wsparcie finansowe musiało być $w$ ratach zwracane.

Gdyby poszukiwać $\mathrm{w}$ tak rozumianej i prowadzonej pracy $\mathrm{z}$ indywidualnym przypadkiem odniesień do nauki, to niewątpliwie odnajdujemy je w psychologii. Stąd korzenie pomagania w modelu medycznym, klinicznym skoncentrowanym na psychoanalizie, psychologii ego, nurcie behawioralno-poznawczym i orientacji humanistycznej [3, c. 30].

Odnosząc się do dzisiejszej rzeczywistości pomocowej, można by widzieć i upatrywać podobnej do tej z czasów dziewiętnastowiecznych postawy wielu klientów instytucji pomocowych. Oczekiwania na państwowe świadczenia socjalne, bez własnego wkładu, gotowości do podejmowania jakichkolwiek wysiłków cechuje ogromną rzeszę naszego społeczeństwa. 
Na przeciwległym biegunie do metody pracy z indywidualnym przypadkiem znaleźli się zwolennicy reform społecznych, jako tych, które odpowiedzialne są za ludzkie nieszczęście i w nich widzieli uzdrowienie sytuacji osób w kryzysach. I tutaj prym wiódł Ruch pracy organicznej (The Settlement Movement) [3, c. 31], a z niego wyrosły settlementy [14]. Przedstawiciele tego ruchu uważali, że tak rozumiana i realizowana «praca $\mathrm{z}$ indywidualnym przypadkiem nie zastąpi działań na rzecz rozwoju lokalnych wspólnot, ani głębszych przemian społecznych. (...) należy zacząć od podstaw - niosąc oświatę i postęp w rejony biedy i zacofania» [3, c. 31]. Ideą przewodnią stało się kształcenie i aktywizacja środowisk najbardziej dotkniętych biedą, ubóstwem i zacofaniem. Stąd jeden z najwybitniejszych prekursorów tej koncepcji brytyjski pastor Canon Samuel August Barnett zamieszkał w ubogiej dzielnicy wśród jej mieszkańców i w relacji partnerskiej, w myśl zasady «przed Bogiem wszyscy są równi» starał się nieść «kaganek oświaty», ucząc zaradności życiowej w relacji przyjaźni i oparcia społecznego.

Tak powstawała kolejna metoda pomagania - metoda grupowa, czerpiąca z naukowego dorobku socjologii. Niewątpliwie jej walory naukowe wnoszą wiele cennych rozwiązań do praktycznie pojmowanej koncepcji pomagania i strategii działania. Jednakże metoda ta nie stanowi przedmiotu analizy autorki.

Wspomniana wcześniej Mary Richmond prekursorka pracy z przypadkiem, twierdziła, że «Na pracę z przypadkiem składają się procesy, które przez świadome dokonywanie indywidualnych aktów dostosowania się jednostek do otoczenia rozwijają osobowość» [15]. Także J. Regensburg odnosząc tę metodę do praktyki pracy socjalnej, widział w niej możliwość, dzięki wsparciu profesjonalisty, tworzenia kontekstu odniesienia się, nazwania przez klienta swojego/swoich problemów i poszukiwania sposobów rozwiązań.

Pewne kontrowersje rozumienia metody pracy $\mathrm{z}$ przypadkiem upowszechnianego na gruncie amerykańskim wyrażali europejscy badacze tej metody. Dyskusyjne stawało się dla nich pozostawanie pracy z przypadkiem pod tak ogromnym wpływem psychologii. Przykładem badacza, który $w$ pracy $\mathrm{z}$ przypadkiem wychodził poza docenianie tylko siły charakteru jednostki i uwzględniał wpływy środowiska był S. Bowers. Według niego metoda pracy $\mathrm{z}$ indywidualnym przypadkiem jest «sztuką, w której wiedza życiowa i nauka o człowieku oraz środowisku, a także umiejętność obcowania z ludźmi - są użyte $\mathrm{w}$ celu zmobilizowania sił w jednostce i odpowiedniej pomocy w społeczeństwie dla ulepszenia wzajemnego przystosowania się jednostki i środowiska» [16]. Te dwa człony: człowiek i środowisko wskazują, że praca z przypadkiem nie może odbywać się w pustej przestrzeni, w oderwaniu od środowiska. Nie może tak być, bowiem człowiek żyje, mieszka, egzystuje w jakimś środowisku, znajduje się wokół niego jakieś otoczenie. Dlatego słuszne wydaje się wspomaganie sił ludzkich w sprzężeniu z siłami środowiska. 
Taką też współzależność sił ludzkich i środowiska w procesie pomagania jednostce widziała i uprawiała na gruncie polskiej pedagogiki społecznej Helena Radlińska. Pracę $\mathrm{z}$ przypadkiem rozumiała jako budzenie, uaktywnianie, mobilizowanie i nakierowywanie jednostki na system działań pomocowych. Ważne w pracy z przypadkiem jest aby bazować na wiedzy psychologicznej, socjologicznej, pedagogicznej, ale i życiowej. Umiejętnie stosować techniki pomocy, uwzględniając potrzeby wewnętrzne jednostki, ale i jej siły i możliwości. Ważne jest usytuowanie problemów osoby w jej środowisku życia.

Odnosząc się do założeń metodycznego działania w pracy z przypadkiem możemy wyróżnić trzy etapy:

1) etap diagnozy - zgromadzenie przy pomocy narzędzia wszystkich potrzebnych danych, dotyczących sytuacji osoby potrzebującej pomocy w jej środowisku (rodzinnym, zawodowym, sąsiedzkim itp.). Następnie krytyczna analiza tych danych przeprowadzona na drodze rozumowania.

2) etap opracowania planu pomocy - profesjonalnie przygotowany do swojej pracy pracownik razem z osobą potrzebującą, przy pełnym zaangażowaniu do współpracy układa plan działania. Istotne jest w tym etapie uwzględnienie nie tylko potrzeb i oczekiwań osoby potrzebującej pomocy, ale i jej możliwości, zasoby, mocne strony.

3) etap prowadzenia przypadku - ten etap jest najsłabiej opisany w literaturze przedmiotu. Być może dlatego, że trudne jest w rzeczywistości zrealizowanie planu pomocy przy ogromnym rozproszeniu służb społecznych (bo głównie do ich pracy odnosimy prowadzenie przypadku). Każda z instytucji pomocowych kierując się swoimi wytycznymi realizuje swoje kompetencje. Każda według własnych procedur nie tyle odpowiada na potrzeby osoby co realizuje swoje zadania.

Prowadzenie przypadku jako etap pracy z przypadkiem powinien być kierowaniem jednostki dwutorowo: po pierwsze - uruchamianiem potencjału jednostki do przystosowania się $\mathrm{w}$ środowisku $\mathrm{w}$ toku relacji pomagającywspomagany, a po drugie - do angażowania w ten rozwój sił tkwiących w społeczeństwie. W tym względzie pomocne mogą być wszelkiego rodzaju instytucje, organizacje $\mathrm{z}$ potencjalnymi usługami wspierającymi i pomnażającymi kapitał jednostki.

Przedmiotem zainteresowań autorki nie jest analiza i opis poszczególnych etapów pracy z przypadkiem, ale zasygnalizowanie próby modyfikowania formuły prowadzenia przypadku (trzeci etap) [10] w koncepcji dostosowywania i dostarczania klientowi potrzebnego mu zestawu usług, po zdiagnozowaniu i ułożeniu planu pomocy przy oszacowaniu zasobów.

Zarządzanie przypadkiem (Case management) wydawać się może zbieżne w swych głównych założeniach do wcześniej opisywanej pracy z przypadkiem. Zdarzają się nawet sytuacje w których pracownicy służb społecznych, bo to u nich 
najczęściej ta metoda występuje stwierdzają ze zdziwieniem, że to wszystko już znają. Owszem, może i znają, może i stosują, ale z jakim skutkiem?

Prawdą jest także, że za prekursorkę dzisiejszego Case managmentu (podobnie jak pracy z przypadkiem) uważa się Mary Richmond. Nic w tym dziwnego, bo główna idea jednej i drugiej formuły są do siebie podobne. Współczesna koncepcja Case Management pochodzi z lat siedemdziesiątych XX wieku ze Stanów Zjednoczonych i funkcjonuje w sektorze socjalnym, szczególne znaczenie ma w opiece zdrowotnej. Także i w Europie znalazła swoje zastosowanie.

0 tym, że jest to godna zainteresowania metoda pracy i uznana w krajach europejskich i na świecie świadczyć może fakt, że powstała amerykańska organizacja «Case Management Society of America» grupująca w swych szeregach profesjonalistów - menedżerów przypadku, którzy posługują się w pracy z klientem modelem case management. Znajdujące się tam zapisy definiują zarządzanie przypadkiem jako: «Case Management jest kooperacyjnym procesem, w trakcie którego planuje się, implementuje, koordynuje, nadzoruje i ewaluuje aktywności pomocowe i usługi, zaspokajając dzięki komunikacji oraz dostępnym zasobom indywidualne potrzeby klienta» [17]. Zaimplementowana na grunt Szwajcarii metoda Case Management przyjmuje rozumienie: «Case Management jest specyficznym postępowaniem w celu koordynacji rozwiązywania kompleksowych zadań w zakresie pomocy społecznej, opieki zdrowotnej i ubezpieczeń. W realizowanym systematycznie i kooperacyjnie procesie CM udostępnia się usługi adekwatne do indywidualnych potrzeb klienta, względnie wspomaga się takie działania w celu sprawnego osiągnięcia wspólnie ustalonych zamierzeń i skutków o wysokiej jakości. CM stanowi sumę działań pomocowych przekraczających granice poszczególnych profesji i instytucji. Respektuje autonomię klienta, wykorzystuje i ochrania zasoby klienta, jak i zasoby systemu wspomagania» [17, c. 30].

Inspiracją do zainteresowania się zarządzaniem przypadkiem jako formułą pracy z klientem stało się $\mathrm{w}$ przypadku autorki tego opracowania porównywanie programu kształcenia na kierunku Praca socjalna w Akademii im. Jana Długosza w Częstochowie (dzisiaj Uniwersytet Humanistyczno-Przyrodniczy im. Jana Długosza) $\mathrm{z}$ programem kształcenia kierunku Case Management $\mathrm{w}$ Hochschule der Bundesagentur für Arbeit (HdBA) w Niemczech. Zbieżność treści modułów realizowanych na obu kierunkach $w$ tych Uczelniach doprowadziła do realizacji międzynarodowego programu w ramach którego studenci Akademii, dzisiaj Uniwersytetu mogli i wciąż mogą realizować specjalność Case management, potwierdzony certyfikatem uczelni partnerskiej. Ten sukces międzynarodowy stał się okazją do poznania specyfiki case managmentu w niemieckiej rzeczywistości w odniesieniu do pracy z osobami bezrobotnymi.

Osoba bezrobotna to przypadek klienta znajdującego się w sytuacji braku pracy, ale i wielu innych problemów, które tworzą spiralę problemów (uzależnienia, przemoc, ubóstwo, problemy zdrowotne, niepełnosprawność itp.). Taką alternatywą 
dla zagubionej tożsamości pracownika socjalnego i niewydolnego systemu pomocy służb społecznych może być modyfikacja modelu kształcenia z uwzględnieniem modułu Case Management/Zarządzanie Przypadkiem, a następnie próba przenoszenia go do praktyki pracy służb społecznych. Innowacyjną w skali kraju próbę aplikacji elementów metody Case Management $\mathrm{w}$ pracy $\mathrm{z}$ klientami $\mathrm{z}$ niepełnosprawnością podjęto $\mathrm{w}$ publicznych służbach zatrudnienia województwa śląskiego [13].

Jest to propozycja bardzo realna bo odnosząca się do działania doradcy klienta z niepełnosprawnością w modelu case managera w służbach zatrudnienia. Podobną $\mathrm{w}$ istocie ideę case managmentu mógłby realizować pracownik socjalny zatrudniany nie tylko w instytucjach pomocy społecznej, ale także w instytucjach organizacyjnych właściwych $\mathrm{w}$ sprawach zatrudnienia i przeciwdziałania bezrobociu, szpitalach, zakładach karnych itp.

Wykorzystywać ją można nie tylko z klientami pomocy społecznej, ale także w pracy z rodzinami, osobami z niepełnosprawnością, starszymi czy innymi grupami społecznymi.

Ta wieloaspektowość sytuacji kryzysowej klienta i jego niezaspokojonych potrzeb zmusza case managera $\mathrm{w}$ Niemczech do pracy $\mathrm{z}$ klientem $\mathrm{w}$ formule zarządzania jego przypadkiem, jego sytuacją. Stąd najczęściej niemieckie definicje modelu case management odnoszą jego zastosowanie do ludzi, którzy znajdują się „W kompleksowym problemowym położeniu, dla którego rozwiązania konieczna jest obecność wielu podmiotów (usługodawców) współdziałających ze sobą w procesie kooperacyjnym (wysokie zagęszczenie podmiotów) [17].

Gdyby przyjąć pojawiające się definicje Case Managmentu moglibyśmy sprowadzić rozumienie tego pojęcia na dwa sposoby.

Pierwszy jako forma pracy $\mathrm{z}$ przypadkiem, zorientowana na zindywidualizowane podejście do potrzeb jednostki rozumianej jako podmiot znajdujący się w trudnej, kryzysowej sytuacji, najczęściej sytuacji wieloproblemowej. Zadaniem case managera jest sporządzenie wywiadu, zaplanowanie działań pomocowych, sterowanie tym procesem oraz ewaluacja aktywności podmiotu ale i usług dostarczających odpowiednie świadczenia. Główny akcent w takim rozumieniu Case Managmentu położony jest na osobistą relację między podmiotem usługi a pomagającym.

Drugi sposób sprowadza się do określenia Case Managmentu jako procesu łączącego zindywidualizowane podejście do klienta z dostarczanymi mu usługami i świadczeniami $\mathrm{w}$ sieci instytucjonalnej. Ważne jest $\mathrm{w}$ tym procesie, aby usługi $\mathrm{w}$ formie pakietu zróżnicowanych ofert dostarczane były w odpowiedniej ilości i jakości oraz czasie.

Gdyby dokonać reasumpcji wcześniej przedstawionych sposobów koncentrowania się na rozumieniu i praktykowaniu Case Managmentu to można by rzec, że pierwszy kładzie nacisk na metodyczne działanie profesjonalisty $\mathrm{w}$ 
zindywidualizowanym podejściu do «pacjenta» (model psychoterapeutyczny, medyczny). Mocno zbieżne rozumienie z prowadzeniem przypadku w klasycznym rozumieniu. Zaś drugi sposób uwypukla jakość organizacji usług (zarządzanie usługami) w sieciowym pakiecie dla «klienta» w zindywidualizowanym podejściu (model systemowy).

Gdyby więc próbować odnieść metodę Case Management do pracy z klientem i prowadzenie go $\mathrm{w}$ formule klasycznej, wcześniej opisywanej to można by powiedzieć, że główny podmiot pracy jest ten sam. Jest nim osoba, człowiek, ale trochę inaczej nazywany i traktowany. W formule klasycznej osoba to pacjent/podopieczny, a $\mathrm{w}$ Case Management to klient. Z takim rozumieniem odbiorcy pomocy łączy się budowanie relacji pomocowej. Pacjent jest zazwyczaj słaby, bo chory, tak więc zależny od lekarza, pielęgniarki, psychoterapeuty zaś klient ma konkretne oczekiwania, nazywa je i oczekuje oferty usługi na jak najwyższym poziomie. W prowadzeniu przypadku profesjonalista motywuje do zmiany, ale czeka cierpliwie na aktywność osoby. W zarządzaniu przypadkiem, nie zarządza klientem, ale jego sytuacją złożoną, wieloproblemową dostarczając mu potrzebne usługi i świadczenia w odpowiedniej ilości, jakości i właściwym czasie.

Kontrola jakości usług dostarczanych przez inne instytucje w Case Managment jest naturalnym elementem pracy. Przyjmuje znaczenie pozytywne, bo poprzez kontrolę można monitorować założony w planie działania czas dostarczanych usług. Ta zasada sprzyja ekonomiczności świadczonej pomocy i ciągłemu jej doskonaleniu. Ponadto klient ma poczucie bezpieczeństwa i sam przyjmuje współodpowiedzialność za realizację zaplanowanych etapów pomocy. Profesjonalni case managerowie mają pełną świadomość, że o skuteczności ich działań decyduje ciągłe ich samodoskonalenie, kształcenie stąd ich wiedza musi mieć charakter interdyscyplinarny (psychologia, pedagogika, socjologia, zarządzanie itp.), ale także znając swoją rolę i prestiż nie boją się konkurencji innych zawodów pomocowych. Współpracują z nimi a nie rywalizują. W systemie pomocowym nacechowanym Case Managment profesjonaliści z sieci usług i świadczeń starają się wykonywać swoją pracę jak najlepiej i najszybciej jak to możliwe. W tym miejscu należy zaznaczyć, że w tym przypadku «szybciej» nie musi znaczyć «gorzej».

\section{WNIOSKI, PERSPEKTYWA DALSZYCH BADAŃ/BИCHOВКИ TA ПЕРСПЕКТИВИ ПОДАЛЬШИХ ДОСЛІДЖЕНЬ}

Zamierzeniem/celem autorki tego opracowania była próba analizy teoretycznej, dotyczącej rozumienia prowadzenia indywidualnego przypadku i Case Management. Jej wyniki sprowadzają się do wyłonienia wniosków:

1. Te dwa sposoby/formy działania oraz procesy je tworzące wywodzą się z uogólnionej teorii i znajdują zastosowanie w różnych wymiarach aktywności społecznej, szczególnie w pracy służb społecznych. 
2.Zasadnicza ich różnica sprowadza się do organizacji i zarządzania strukturą organizacyjną instytucji w której dominuje technologia Case Management, prowadzona przez odpowiedzialną, wykształconą zarządczo kadrę.

3. Ważne dla sprawnego funkcjonowania Case Managment w praktyce jest to, aby był on wdrażany na trzech poziomach:

I poziom makro - CM jako cel polityki społecznej, poprzez regulacje normatywne.

II poziom mezo - CM realizowany w organizacji, poprzez regulacje prawne normujące zarządzanie instytucją oraz wyznaczanie wewnętrznego administrowania osób (personelu) odpowiedzialnych za realizację zadań na dwóch poziomach: wewnątrz instytucji $\mathrm{z}$ beneficjentami i zewnętrznymi interesariuszami.

III poziom mikro - CM w kontekście operacyjnym, poprzez bezpośredni kontakt z jednostką.

Perspektywa dalszych badań sprowadza się do rozpoznawania w teorii i w praktyce możliwości wprowadzenia do pracy służb społecznych (i nie tylko) formuły Case Management poprzez realizowanie jej na trzech poziomach polityki społecznej: normatywnym (formalno-prawnym), organizacyjnym (instytucjonalnym) i operacyjnym (z klientem). To przedsięwzięcie badawcze mogłoby dać szansę na sprawną reorganizację zindywidualizowanego i zintegrowanego systemu usług. Zarządzanie takim procesem to perspektywa na profesjonalną strukturyzację przebiegu działania - zarządzanie obszarami oraz sieciami.

\section{LITERATURA}

[1] Г. Бевз. «Психологічна робота в практиці кейс-менеджменту: аналіз досвіду впровадження», Psychological journal, № 3(13). с. 9-20, 2018. [Електронний ресурс]. Доступно:

https://doi.org/10.31108/2018vol13iss3.

[2] О. Савчук, К. Сініцина, та О.Савчук «Робота 3 випадком», на Всеукраїнській благодійній організації «Всеукраїнська Мережа ЛЖВ», 2013, 60 c.

[3] D. Howe, Krótkie wprowadzenie do teorii pracy socjalnej. Warszawa, 2011, S. 29.

[4] T. Kaźmierczak, and M. Rymsza, Case management jako formuła koordynacji usług społecznych i innych działań służb publicznych - przypadek aktywizacji zawodowej i społecznej osób niepełnosprawnych [w:] Profesjonalna praca socjalna. Nowy paradygmat czy niedokończone zadanie? redakcja naukowa Krzysztof Piątek, Katarzyna Szymańska-Zybertowicz. Toruń. 2011, Wydawnictwo Edukacyjne «AKAPIT», s. 229-249. 
[5] T. Klie, Zarządzanie przypadkiem a usługi społeczne, [w:] Podręcznik usług społecznych-przykład Niemiec, red. A. Evers, R. G. Heinze, T. Olk, przekład K. Sosnowska, Redakcja naukowa i językowa przekładu M. Grewiński, E. Przedecka. Warszawa, 2013.

[6] M. Mirowska, Case Management jako przykład nowoczesnego kształcenia studentów, Uniwersytet Zarządzania Oświatą NAPN Ukrainy. Kijów, Післядипломна освіта в Україні, 2016, s. 65-69.

[7] M. Mirowska, Case management (zarządzanie przypadkiem) jako społeczno-inwestycyjny element systemu usług społecznych, Sumy State Pedagogical University named after A.S. Makarenko. Педагогічні науки: теорія, історія, інноваційні технології, № 5(59), s. 442- 448, 2016.

[8] M. Mirowska, Case management (zarządzanie przypadkiem) jako technologia przyszłości w szkole wyższej. Педагогічні науки: теорія, історія, інноваційні технологіï, № 6 (70), s. 108-116, 2017.

[9] M. Mirowska, Innowacyjna formuła prowadzenia przypadku, Pedagogika, T. 23; Częstochowa 2014.

[10] M. Mirowska, Wartość pracy socjalnej w kontekście rozwiązywania problemów jednostki, Zarzadzanie i Edukacja. Warszawa, Nr 105, 2016.

[11] M. Mirowska, Zarządzanie przypadkiem $50+\mathrm{w}$ pracy socjalnej, [w:] Aktywizacja zawodowa osób 50+ wyzwaniem dla rynku pracy, redakcja naukowa B. J. Ertelt, J. Górna, Wydawnictwo AJD, Częstochowa, 2015.

[12] Poradnik Elementy metody Case Management $w$ pracy $z$ klientami $z$ niepełnosprawnościq $w$ publicznych służbach zatrudnienia województwa śląskiego, konsultacje naukowe B. J. Ertelt, M. Mirowska, Wydawnictwo Grafpol. Wrocław, 2015.

[13] J. Przywojska, Nowe zarzq̨dzanie i governance w pracy socjalnej. Warszawa, 2014, s. 40.

[14] R. A. Skidmore, and M. G. Thackeray, Wprowadzenie do pracy socjalnej. Katowice, 1998, s. 61.

[15] Z. Ostrihanska, and A. Greczuszkin, Praca z indywidualnym przypadkiem $w$ nadzorze rodzinnego kuratora sq̨dowego. Lublin 2000, s. 40.

[16] A.Smrokowska-Reichmann, Zarządzanie przypadkiem - Case Management (CM) w pracy socjalnej [w:] Nowe kierunki i tendencje $w$ organizacji $i$ zarzq̨dzaniu pomocq społecznq, red. A. Skowrońskiej. Warszawa, 2013, s. 29. 


\title{
ВЕДЕННЯ ІНДИВІДУАЛЬНОГО ВИПАДКУ ТА УПРАВЛІННЯ ВИПАДКОМ: ТЕОРЕТИЧНИЙ АНАЛІЗ
}

\author{
Маріола Міровська, \\ кандидат гуманітарних наук в галузі педагогіки, \\ керівник закладу соціальної роботи і суспільного розвитку; \\ педагогічне відділення, \\ Університет ім. Яна Длугоша в Ченстохові \\ (Республіка Польща) \\ ORCID iD: https://orcid.org/0000-0002-4257-1528 \\ mmirowska@interia.pl
}

Анотація. Стаття присвячена теоретичним міркуванням щодо ведення випадку та кейс-менеджменту, що трактується як управління випадком. Ключовим $\epsilon$ не лише розрізнення розбіжностей та схожості в теоретичному обсязі обох методів, але й вирізнення двох суттєвих компоненти, які в педагогічному, соціальному, освітньому форматі мають інший напрямок спрямування. Суттєва їхня відмінність і перевага, на думку автора цього дослідження, у розмірі практичної допомоги саме і викликає дослідницький інтерес до методу. Опираючись на літературний аналіз предмету генезису обох понять то їх теоретичного підгрунтя базовим можна вважати саме роботу з індивідуальним випадком. Метод має американське походження, а його засновником була Мері Річмонд. У методі індивідуального випаду виділяється два компоненти. Одним 3 них $€$ розпізнавання ситуації користувача (внутрішньої та зовнішньої) та її проблематики (діагностування ситуації), що зумовлює формулювання разом 3 користувачем робочого плану іï урегулювання. Другим компонентом $\epsilon$ безпосередня праця із випадком на основі визначеного плану. Обидва компоненти рівноправно існують у роботі по «веденню випадку» а також «управління випадком». Натомість метод «управління випадком» включає в себе компонент індивідуального підходу до одержувача а також підтримує мережу взаємозв'язаних сервісів, що надходять з різних джерел, необхідних та доставлених у потрібній кількості та у потрібний час. Розуміння та впровадження ідеї управління випадком клієнта на трьох рівнях соціальної політики (нормативна, організаційна та безпосередньо-операційна), може дати шанс на ефективну реорганізацію сервісної системи установи як індивідуально-інтегрованої. Управлінням таким процесом $\epsilon$ професійне структурування курсу дій, управління областями та системами мереж. 
Для поліпшення якості практики надання допомоги важливо вивчити ефективність надання допомоги як в напрямку методології діяльності так і технології надання послуги (економічний вимір). У цьому відношенні кейс-менеджмент $\epsilon$ інноваційною технологією організації та управління організаційною структурою установи, яка об'єднує як компонент індивідуального підходу до одержувача так і мережу взаємозв'язаних послуг.

Ключові слова: кейс-менеджмент, індивідуальний випадок, праця 3 індивідуальним випадком, ведення випадку, мережа підтримки.

\title{
INDIVIDUAL CASEWORK AND CASE MANAGEMENT: THEORETICAL ANALISIS
}

\author{
Mariola Mirowska, \\ Candidate of Humanities in the field of pedagogy, \\ Head of the institution of social work and social development; \\ pedagogical department \\ University of them Yana Dlugosha in Czestochowa \\ (Republic of Poland) \\ ORCID iD: https://orcid.org/0000-0002-4257-1528 \\ mmirowska@interia.pl
}

Abstract. The article is devoted to academics regarding casework and
Case management interpreted as service coordination.
Its theoretical underground can be intimately considered the work with an
individual case relying on the literary analysis of the genesis subject of
both concepts. The method is of American origin, and Mary Richmond was
its founder. The key point is not merely to distinguish differences and
similarities in the theoretical volume of both methods, but also to
determine two significant components oriented towards a reversed
direction in the pedagogical, social and educational form. According to the
author of this study, its crucial difference and advantage involving the
extent of practical assistance provoke the research interest in the
method.Two components are distinguished in the individual case method.
The first is the recognition of the user's situation (internal and external)
and their problems (diagnosis of the situation), which causes the
formulation of the work plan for its arrangement together with the user.
The second component is direct work with a case based on the defined
plan. Both components are equal in the operation on "casework" as well as
"Case management". However Case management method includes a
component of the individual approach to the recipient and also supports a
network of interrelated services coming from different sources, needed
and delivered at the right amount and at the proper time. Understanding 
and implementing the idea of managing a client case at three levels of social policy (normative, organizational and directly operational) can give a chance to an effective reorganization of the institution service system as an individually integrated one. Management of such a process is the professional structuring of the action course, managing the areas and network systems. It is important to study the effectiveness of assistance in both the methodology of activities and the technology of service delivery (economic dimension) in order to improve the quality of providing assistance. In this view, Case Management is an innovative technology of organizing and managing the organizational structure of the institution integrating both the component of the individual approach to the recipient and the network of interrelated services.

Keywords: Case management, individual case, work with an individual case, casework, support network.

\section{REFERENCES (TRANSLATED AND TRANSLITERATED)}

[1] H. Bevz. «Psykholohichna robota v praktytsi keis-menedzhmentu: analiz dosvidu vprovadzhennia», Psychological journal, № 3(13). s. 9-20, 2018. [Elektronnyi resurs]. Dostupno: https://doi.org/10.31108/2018vol13iss3.

[2] O. Savchuk, K. Sinitsyna, ta O. Savchuk «Robota z vypadkom», na Vseukrainskii blahodiinii orhanizatsii «Vseukrainska Merezha LZhV», 2013, $60 \mathrm{~s}$.

[3] D. Khove, Short introduction, in the theory of social labour. Warsaw, 2011, s. 29.

[4] T. Kazhmierczak, and Rimsza, Case of management, both the formula of coordination of public services and other actions of public services is a case of professional and public activation of incompleteclear [in:] persons Professional social labour. New paradigm or unfinished task? scientific release Khrystofor Piatek, Kateryna Szimanska-Zibertovicz. Torun. 2011, Educational publishing House «INDENTION», s. 229-249.

[5] T. Klie, Management, by chance and public services, [in:] Textbook of services of spolecznickh-prziklad Germany, editor, Or Evers, in O'clock of Kheinze, T. Olk, translation, Near Sosnovska, scientific and linguistic Release of translation Grevinski, E. Przedecka. Warsaw, 2013.

[6] Case Management both the example of the modern enlightening of students, Management University, Mirovska by Formation of NAPN of Ukraine. Kyiv, Pisliadyplomna osvita v Ukraini, 2016, s. 65-69.

[7] Case of management (management by chance) both the public-investment element of the system of public services, Sumi of State Pedagogical Universiti of named of after, Mirovska Or S. Makarenko. Pedahohichni 
nauky: teoriia, istoriia, innovatsiini tekhnolohii, № 5(59), s. 442-448, 2016.

[8] Case of management (management by chance), Mirovska both technology of the future at higher school. Pedahohichni nauky: teoriia, istoriia, innovatsiini tekhnolohii, № 6(70), s. 108-116, 2017.

[9] Innovaciyna formula of conduct of case, Pedagogics, M. Mirovska. 23; 2014. Czestockhova.

[10] Cost of social labour in the context of decision of problems of individual, Management and Education, Mirovska. Warsaw, Nr 105, 2016.

[11] Management, Mirovska by chance 50 + in social labour, [in:] professional Activation of persons $50+$ calling for a labour-market, scientific release Very much Y. Ertelt, Y. Overhead, publishing House of AYD, Czestockhova, 2015.

[12] Reference Book Elements of method of Case Management in labour with clients with incomplete preparedness in public services of employment of slaskiego province, scientific consultations Very much Y. Ertelt, publishing House of Grafpol Mirovska. Vroclav, 2015.

[13] Y. Przivoyska, New management and governance, in social labour. Warsaw, 2014, s. 40.

[14] In. Or. Skidmore, and O'clock of Tkhackerai, Introduction, in social labour. Katovice, 1998, s. 61.

[15] With. Ostrikhanska, and, Or Greczuszkin, Labour with an individual case in the supervision of domestic judicial counsel. Lublin 2000, s. 40.

[16] Or. Smrokovska-Reickhmann, Management by chance - Case Management (SEE) in social [in:] labour New directions and tendencies in organization and management by a public help, editor Or Skovronskiey. Warsaw, 2013, s. 29. 